\title{
臨床
}

\section{口腔機能障害の軽減をめざした口腔癌に対する 導入化学・放射線治療と保存的手術}

\author{
尾 崎 登喜雄, 広 田 重 水, 米 田 和 典 \\ 山本哲 也, 植 田栄 作
}

要旨: 保存的切除を目的に術前化学・放射線治療が64例の口腔癌, 一次症例に施行され た。対象は T1：2 例, T2：27例, T3：22例, T4：13例であった。Peplomycin, 5-fluorouracil, Cisdichlorodiamine-platinum らのうちの単剂, あるいは併用からなる化学療法と 共に, ${ }^{60} \mathrm{Co}$ による外照射が同時に行われた。導入治療の臨床効果は, CR 22例, PR ( $90 \%$, 縮小率) 17 例, $\mathrm{pR}^{\prime}$ ( $\geqq 50 \%$ ) 22例，NR 3 例であった。切除物の組織学的検索よ り, Grade IV : 16例, Grade III $: 4$ 例, Grade II b : 33例, Grade II a $: 4$ 例, Grade I : 1 例の結果が得られた。そして, 臨床効果と組織学的効果との間に相関がみられた。 各々の切除量は, 導入治療の臨床効果を考慮して決定され，4段階に分類された。 grade I (外科的処置なく経過観察, あるいは生検切除), あるいは grade II (舌の辺 縁切除, 口底および煩粘膜の表層, あるいは限局した切除, 歯肉を含めた歯槽骨切除) は，それぞれ15例であった。grade III（周囲組織を含めた舌 $1 / 3$ までの切除，口底に限局 した pull-through 手術, 皮膚が保存された煩粘膜の切除, そして下顎管までの下顎骨辺 縁切除）の手術が22例に施行され，根治拡大手術である grade IV は12例に施行された。 このように大多数の腫場は保存的に切除され, 即時再建は23例に DP 皮弁が, 4 例に筋皮 弁が用いられた。

対象のうち 10 例に局所再発がみられたが, これらのうち 6 例は二次的に制御し得, 最 終局所制御率は $93.8 \%$ であった。また全体の 5 年累積生存率は $69.4 \%$ であった。

口腔機能を測定したところ, 発音は36例の舌・ロ底癌のうち15例に障害がみられたが, 中程度ないしは強度の障害は 5 例にみられたにすぎなかった。味覚障害は治療と共に増 悪したが, 治療後 1 年のうちに元のレベル近くまで回復していた。安静時唾液分泌量は 徐々に低下し, 治療後 1 年には治療前の約半分にまで低下した。唾液分泌量の低下に伴 って, 唾液粘稠度は増加し, S-IgA 濃度は分泌量と同じく低下していた。これらの結果 より, 化学・放射線の同時併用からなる積極的な導入治療は保存的切除を可能にし, 口 腔機能障害を減じることが示された。しかし一方では, 導入治療は唾液腺機能及び味覚 の低下を来し, 粘膜反応も強いことより, 用量を減じるべく工夫が必要と思われた。

キーワード : 口腔癌, 導入治療, 臨床組織学的効果, 保存的手術, 口腔機能

\section{緒言}

口腔癌の治療が進歩し，局所制御率，生存率が高く なるにつれて，口腔・顎・顔面の機能である発音，咀
嚼，與下ならびに審美性をいかに保存して治療するか が工夫されるようになり, 癌治療における quality of life が問われる時代となった ${ }^{1 \sim 3)}$ 。口腔癌治療は以前に は手術と放射線療法が主体をなし，化学療法は補助的 
Table 1 Clinical Characteristics of 64 Primary Oral Cancer Patients Subjected

\begin{tabular}{llrl}
\hline Age & Mean & 61.8 & \pm 10.9 \\
& Range & 33 & 92 \\
Sex & Male & 41 & \\
& Female & 23 & \\
Site & Tongue & 26 & \\
& Gingiva & 25 & \\
& Floor & 10 & \\
T-stage & Cheek & 2 \\
& T1 & 27 \\
& T2 & 22 \\
Stage & T3 & 13 \\
& T4 & 1 \\
& I & 17 \\
& II & 23 \\
\hline
\end{tabular}

手段にすぎなかったが，近年，扁平上皮癌に有効な薬 剤が開発されるにつれて，化学療法を含めた集学的治

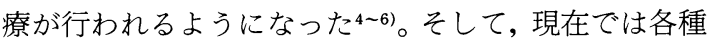
抗癌剂と放射線の併用による積極的な術前治療が施行 され，より良好な治療効果があげられている7 9)。口 腔・顔面は機能面と審美性の面より, 治療は可及的に 外科的侵襲の少ないことが望まれる。それゆえ，実効 ある導入療法が必要となり,その効果が十分であれば, 切除は行わずとも良いことになり，切除するとしても 切除範囲は小さくすることができ，それがひいては機 能保存と審美性の確保につながることとなる。このよ うな観点に立ち，われわれは，Peplomycin (PLM)を 中心とした化学療法と共に, ${ }^{60} \mathrm{Co}$ による外照射の同時 併用を試みてきた ${ }^{10,11)}$ 。しかし一方では, 抗癌剤, 放射 線照射は顎, 口腔組織に障害を与え, 口腔粘膜炎をは
じめ，唾液分泌，味覚の低下を来す。そして外科療法 による発音・発語, 咀嚼, 嚥下等の機能障害と審美性 の傷害は多少とも避け難(12,13)。そこで, より効果的 で, かつ, 機能障害の少ない口腔癌治療を追求すべく, 本論文では，化学・放射線による先行治療と，それに 続く保存的手術の有用性を検討すると共に, 治療に伴 う障害に関しても検討を加えた。

\section{対象および方法}

昭和56年11月から平成 2 年11月末までの約 9 年間に 当科で加療した口腔扁平上皮癌一次症例の中で, 導入 治療として化学・放射線の併用療法を行った64例を対 象とした。症例の内訳は Table 1 の如くで, 舌26例, 歯肉25例，口底10例，煩粘膜 3 例であった。これら64 例の T stage 分類 (1987年 UICC) は T1：2 例, T2 : 27例, T3：22例, T4：13例であり, 病期別分類では I 期：1例, II 期 $: 17$ 例, III期：23例, IV 期：23例であ つた。なお，歯肉癌においては，歯槽骨に比較的限局 した骨吸収がみられても，それを考慮せず，歯肉の病 巣の大きさでもってT分類を行った。化学療法として は, Peplomycin (PLM) 単独：5例, PLM+5-fluorouracil (5-FU) : 44例, 5-FU+Cisdichlorodiamineplatinum (CDDP) : 1 例, PLM+5-FU+CDDP : 14 例となっていた。PLM は $5 \mathrm{mg} /$ 回を週 3 回，隔日に， 5-FU は放射線照射直前に $250 \mathrm{mg} /$ 日を週 5 回，そして $\mathrm{CDDP}$ は30〜 $50 \mathrm{mg} / \mathrm{m}$ を 2 回ないし 3 回，外照射中に 静脈内投与した。これらの化学療法と共に，1 回に 2

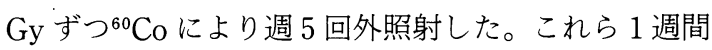
単位の治療を 3 回繰り返すことを原則としたが，治療

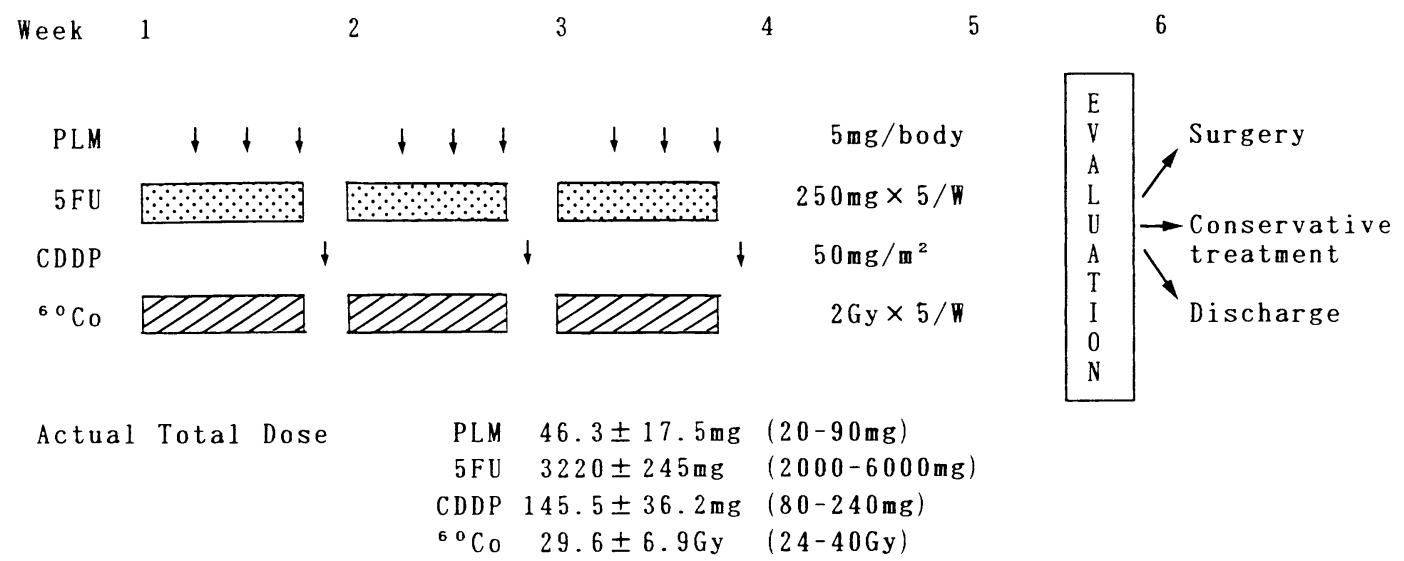

Fig. 1 The principle of Induction Therapy 
Grade I : Excisional biopsy or observation without surgery

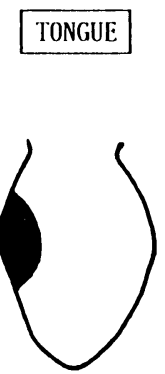

marginal -ectomy

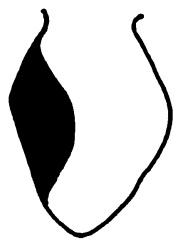

$<1 / 3$ with

limited

floorectomy

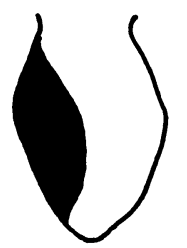

$>1 / 3$ with

wide

surrounding tissue ectomy
FLOOR

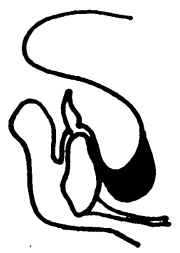

superficial

floorectomy

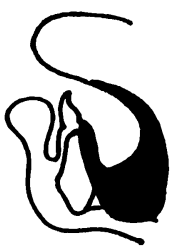

pull through ectomy without wide surrounding tissue

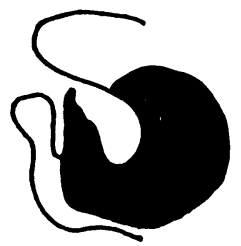

pull through with glossoand mandibulectomy
GINGIVA

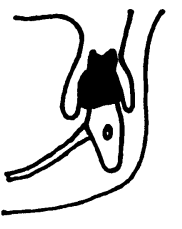

alveolectomy

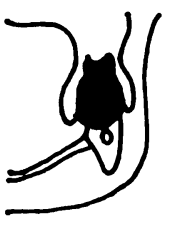

above canal mandibulectomy

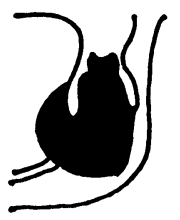

mandibulectomy with floor ectomy
CIIEEK

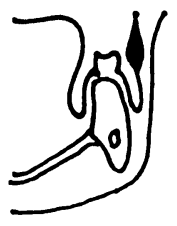

superficial eclomy

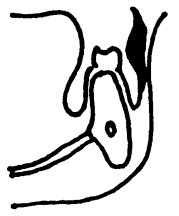

skin-conservated wide excision

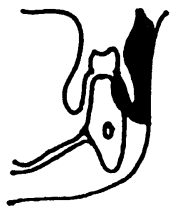

full thick excision with gingivectomy

Fig. 2 A Proposal on Grading of Excisional Extent in Oral Carcinomas

効果, 副作用の程度により投与間隔, 投与量, および 照射量ともに増減し， 1 症例当りの平均投与量は, PLM : 46.3 $\pm 17.5 \mathrm{mg}, 5$-FU : $3220 \pm 245 \mathrm{mg}$, CDDP : $145.5 \pm 36.2 \mathrm{mg}$ ，そして照射量は $29.6 \pm 6.9 \mathrm{~Gy}$ であっ た(Fig. 1)。なお，一部の症例では，支配動脈を用い， PLM あるいは 5-FU の動注を行った。また，PLM は 一部において筋注投与を行った。

臨床効果の評価は, 導入治療終了後, 2 週間経た時 点で行い, 治療効果に応じて手術の適応と切除量, 更 なる保存的治療，あるいは退院のいずれかを決定した。 術前治療の臨床的効果は頭頸部がん治療効果判定基 準 ${ }^{14)}$ に則り縮小率を算定し, $\mathrm{CR}$ : 病変の完全消失, $\mathrm{PR}: 90 \%$ 以上の縮小, $\mathrm{pR}^{\prime}: 50 \%$ 以上 $90 \%$ 未満の縮
小，NR：50\%未満の縮小，の 4 段階に分けて判定し た。

手術の適応そして切除範囲は臨床効果に基づき決定 し, 各々の切除量 (手術侵襲)を 4 段階に分類した (Fig. 2)。すなわち, 手術は行わず経過観察を行うか, ある いは病巣はほとんど消失しているものの, かつては腫 瘍の中心部であった部位にわずかに残存する瘢痕状組 織に対し生検切除を行ったものを I 度とし, II 度は 各々の原発部位である舌, 歯肉, 口底, そして煩組織 の辺縁, あるいは表層部の切除で留め得たものとした。 III 度は舌癌の場合, 舌 $1 / 3$ までの切除に口底の小範囲の 切除が加わったもの, 歯肉癌においては下顎管より上 方の顎骨の切除を行ったもの, 口底癌では部分的な舌 
Table 2 Clinical Response to Induction Therapy

\begin{tabular}{|c|c|c|c|c|c|c|c|c|c|c|}
\hline \multirow{2}{*}{ Response } & \multirow{2}{*}{$\begin{array}{c}\text { Remission } \\
\text { rate }\end{array}$} & \multicolumn{4}{|c|}{ Site } & \multicolumn{4}{|c|}{$\mathrm{T}$-stage } & \multirow{2}{*}{ Total (\%) } \\
\hline & & Tongue & Gingiva & Floor & Cheek & $\mathrm{T} 1$ & $\mathrm{~T} 2$ & $\mathrm{~T} 3$ & $\mathrm{~T} 4$ & \\
\hline $\mathrm{CR}$ & $100 \%$ & 9 & 10 & 2 & 1 & 1 & 10 & 8 & 3 & $22(34.4 \%)$ \\
\hline PR & $\geqq 90 \%$ & 8 & 5 & 3 & 1 & 0 & 7 & 6 & 4 & $17(26.6 \%)$ \\
\hline $\mathrm{pR}^{\prime}$ & $\geqq 50 \%$ & 9 & 8 & 4 & 1 & 1 & 9 & 7 & 5 & $22(34.3 \%)$ \\
\hline NR & $<50 \%$ & 0 & 2 & 1 & 0 & 0 & 1 & 1 & 1 & $3(4.7 \%)$ \\
\hline
\end{tabular}

切除を含めた pull through operation で顎骨が保存さ れた場合とし，煩粘膜癌では外層の皮膚が保存された ものとした。 IV度は各々の原発組織が III 度以上となり， より広範な周囲組織の切除を行った場合とした。

組織学的な検索は, 切除物を "bread loaf method" にてブロック分けし，各ブロックより数枚の薄切標本 を作成し，全割半連続切片とし全体的に検討した。そ して, 組織学的な治療効果を下里の分類 ${ }^{15)}$ 用いて評 価した。

発語明瞭度を治療後 3 か月の時点で，舌および口底 癌症例に限定して行った。発語明瞭度は, 患者に母音, 無声音, 有声音, 鼻音の順で100語を音読させ, これを 録音し，この録音された音声を 4 人の健聴者が聴取し 求めた ${ }^{16)}$ 。明瞭度は正しく恥取された語数 (百分率)で もって表し，4 人が判定した明瞭度の平均值を求め, その值を $100 \%, \geqq 95 \%, \geqq 80 \%, \geqq 50 \%,<50 \%$ の 5 段 階に分類した。

味覚検查は，基本味である甘味，塩味，酸味，苦味

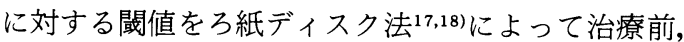
導入療法終了後, 治療後 3 か月および 1 年の計 4 回測 定した。閾値は，5段階に希釈した各々の濃度の味質 溶液を直径 $5 \mathrm{~mm}$ のろ紙ディスクに充分に湿らせ，舌背 に設置した後，患者に味を申告させることにより求め た。つまり，1段階ずつ濃度を高めて行き，味を正し く認識した最低濃度をもって閥值とし, 最高段階希釈 濃度でも味を識別できなかった時には閾値を「6」と した。

安静時唾液分泌量の測定は, 口底にあらかじめ重量 を測定しておいた綿花を置き，10分間に分泌された無 刺激混合唾液を採取した。そして，唾液が浸潤した綿 花の重量 $(\mathrm{g})$ を測定し, 増加した重量を求め, $1 \mathrm{~g}$ を
$1 \mathrm{ml}$ とて分泌量（ml）に換算した。重量計測後，唾 液を $3,000 \mathrm{rpm}$ で遠沈し, その上清を $-20^{\circ} \mathrm{C}$ にて保存 し, 粘稠度および S-IgA の測定に供した。唾液粘稠度 は，凍結保存した唾液を室温にて溶解し30分間放置し た後, 粘稠度測定器 (ビスメトロン, 東芝 $\mathrm{K} \cdot \mathrm{K}$, 東京) でもって測定した。測定は 3 回繰り返し, その平均值 を求めた。一方, S-IgA は EIA：S-IgA テスト液 (医 学生物学研究所, 名古屋) を用いて測定した。唾液 10 $\mu 1$ を反応用暖衝液にて 40 倍に希釈し, キット液と反応 させ, 微量分光光度計 (Du-50, Beckman) で492nm に おける吸光度を 2 回測定した。そして既知濃度の SIgA より得た標準曲線に照会し, 検体中の S-IgA 濃度 を求めた。

\section{結果}

導入療法によって CRが22例（34.4\%）に得られ (Table 2), これらの内の 6 例は外科的処置を受けない ままに，以後も局所制御されていた。PR は17例(26.6 \%)で， CR と PR を合せると，全体の 6 割以上を占め ていた。一方, $\mathrm{pR}^{\prime}$ は22例(34.3\%), NR はわずか 3 例 であった。臨床効果を部位別にみると，舌および煩粘 膜癌における $90 \%$ 以上の縮小例は，それぞれ 26 例中 17 例， 3 例中 2 例であり，歯肉癌の 25 例中 15 例，そして 口底癌の 10 例中 5 例に比しやや多くみられたものの, 有意差は得られなかった。さらに腫場の大きさと縮小 率との関係において，90\%以上の腫瘍縮小が T1の 2 例中 1 例, T2の 27 例中 17 例, T3の 22 例中 14 例, T4の 13 例中 7 例に認められた。したがって，T4症例において やや効果が劣る結果となっていたが，T2，T3との間に は大きな差は認められなかった。

組織学的な治療効果は, grade IV : 16例, grade III： 
Table 3 Correlation between the Clinical and Histopathological Effects

\begin{tabular}{ccccccc}
\hline \multirow{2}{*}{$\begin{array}{c}\text { Clinical } \\
\text { effect }\end{array}$} & \multicolumn{5}{c}{ Histological effect } & Total \\
\cline { 2 - 5 } CR & IV & III & IIb & IIa & I & \\
\hline PR & 3 & 3 & 10 & 1 & 0 & 16 \\
pR' & 2 & 0 & 16 & 3 & 1 & 22 \\
NR & 0 & 0 & 3 & 0 & 0 & 3 \\
\hline Total & 16 & 4 & 33 & 4 & 1 & 58 \\
\hline
\end{tabular}

Among 22 CR instances, 6 cases who received no surgery are excluded in the table. A highly significant correlation between the clinical effects and the histopathologic degenerative effects was obtained ( $\mathrm{p}<0.001$ by $x^{2}$-test).
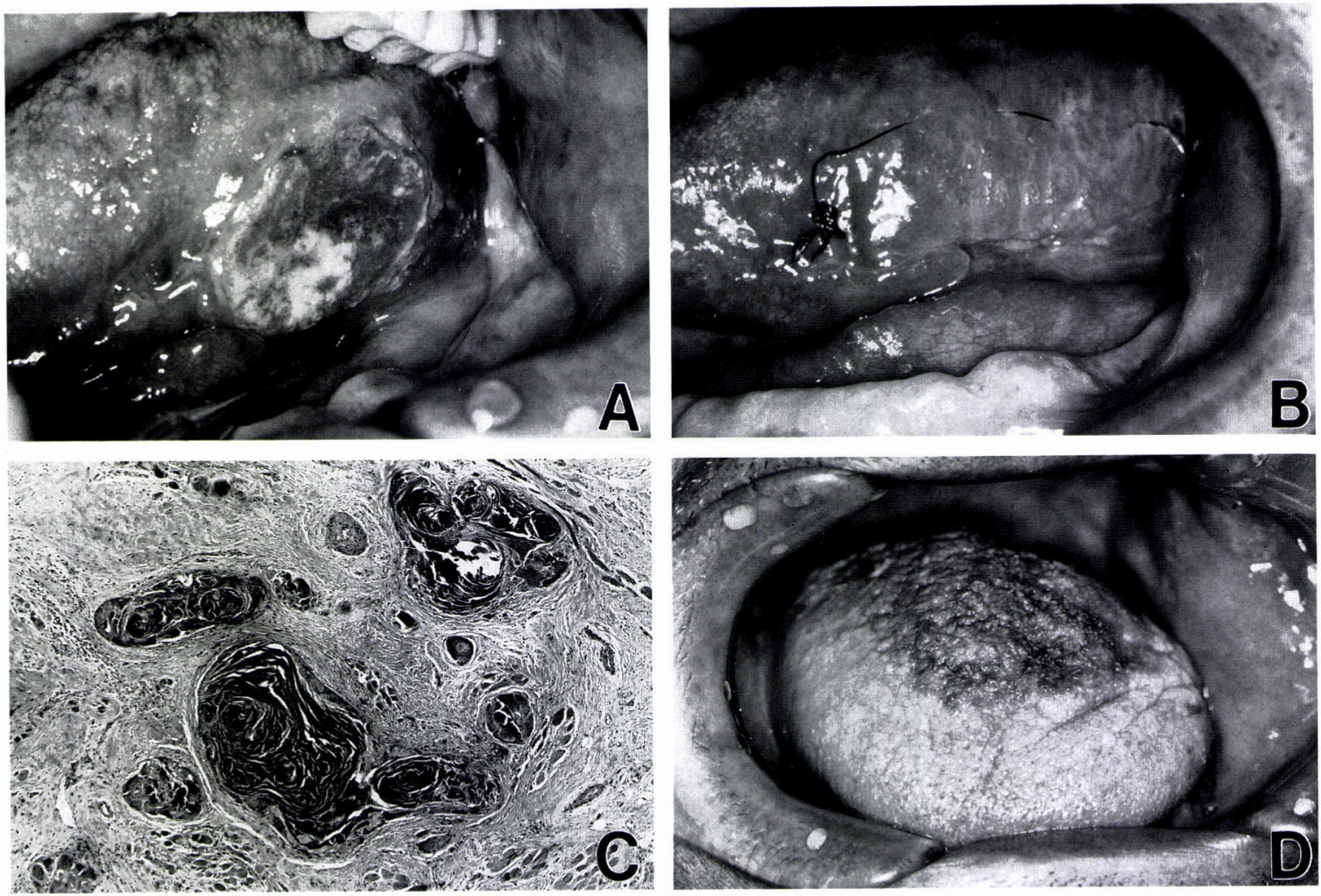

Fig. 3 Stage II carcinoma originated from the left side of the tongue (A), which completely diminished responding to combined induction therapy with PLM, $5-\mathrm{FU}$ and ${ }^{60} \mathrm{Co}(\mathrm{B})$. The microscopy of the specimens of the extirpated material shows no survival cancer cells, being considered as Grade IV (C, H $\& \mathrm{E} \times 320$ ). Two months after surgical treatment. No deformity of the operated tongue is remained (D). 

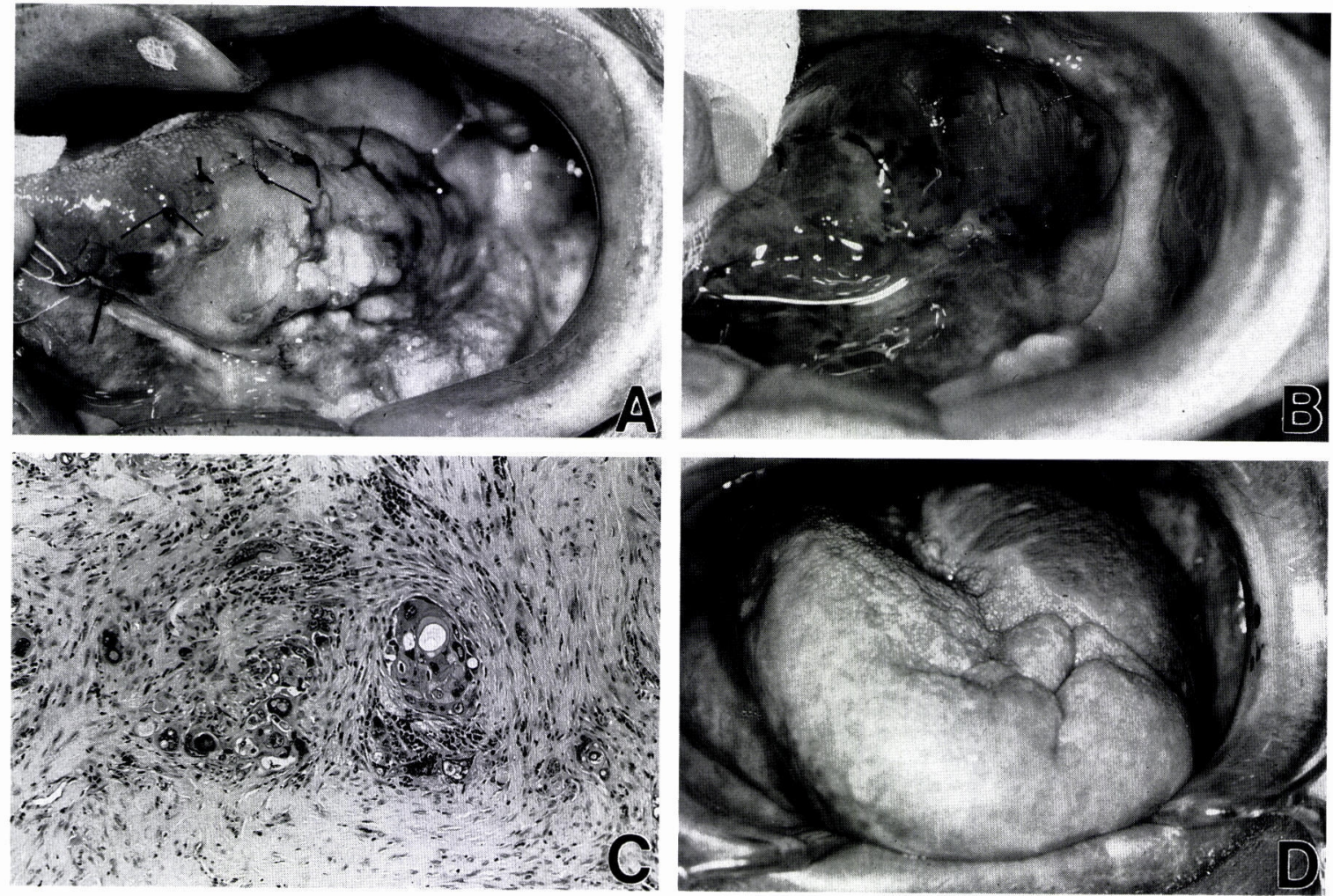

Fig. 4 A tongue carcinoma of T3N1 (A). The clinical effect of induction therapy was evaluated as PR (B), and the histopathologic effect as Grade $\mathrm{IIb}(\mathrm{C}, \mathrm{H} \& \mathrm{E} \times 560)$. The tongue defect was immediately reconstructed with DP flap. Photograph D shows the clinical appearance at 3 months after the operation.

4 例, grade II b：33例となっており, grade II a は 4 例, grade I はわずかに1例であった（Table 3)。 組織学的な治療効果と臨床効果との関係についててみる と, CR の16例のうち11例は grade IVで, grade III : 1 例, II b： 4 例となっており, 全例とも grade II b 以 上の効果が示された（Fig. 3)。PR では grade IV : 3 例, III : 3 例, II b : 10例, II a : 1 例で, CR におけ るよりも少し劣っていた（Fig. 4)。pR'の22例の中に grade IVが2例みられたが，多く(16例) は grade II b で, grade II a が 3 例, grade I が 1 例であった。NR の 3 例はすべて grade II bであった。これらの結果を まとめると, 腫瘍の縮小程度と病理組織学的な効果と は関連性が認められ，両者の間には強い相関が得られ た $\left(\mathrm{P}<0.001 . x^{2}\right.$-test)。なお， $\mathrm{CR}$ のうちの 6 例は 導入療法のみで再発なく制御されていることより, 組 織学的には grade IVかIII と想定されるが，これらは上 記の結果に含められていない。
手術侵襲が I 度であった症例は，舌および歯肉癌の 15例で, このうち 9 例に生検切除がなされ, 残る 6 例 は外科処置がないままに経過観察とされた (Table 4)。 ついでII度は 15 例, III 度は対象の約 $1 / 3$ に当たる22例と なっていた。広範な切除である IV 度は，煩粘膜癌では みられず，また，舌・口底癌合せた 36 例のうち 7 例に すぎなかった。なお，下顎歯肉癌の 25 例中わずかに 5 例が下顎半側切除ないしは区域切除をうけていた。

即時再建は30例（46.6\%）に施行されていた。舌癌 では26例中 Deltopectoral skin flap（DP 皮弁）が 5 例, 大胸筋皮弁 (単に MC 皮弁) が 2 例, Leslie 法191 による舌分割皮弁が 3 例に用いられた。即時再建術が 行われた下顎歯肉癌の10例はすべて DP 皮弁により再 建され，骨の欠損に対しては腸骨移植が 1 例に施行さ れていた。口底癌では10例中 8 例に再建術が行われて おり, DP 皮弁が 6 例に, そして $\mathrm{MC}$ 皮弁が 2 例に用い られた。煩粘膜癌では 2 例とも DP 皮弁により再建さ 
Table 4 On Excisional Extent and Immediate Reconstruction

\begin{tabular}{|c|c|c|c|c|c|c|c|c|}
\hline \multirow{2}{*}{ Site } & \multirow{2}{*}{ No. } & \multicolumn{4}{|c|}{ Grade of excision $※$} & \multicolumn{3}{|c|}{ Reconstruction } \\
\hline & & I & II & III & IV & $\mathrm{DP}+$ & $\mathrm{MC} \ddagger$ & Others \\
\hline Tongue & 26 & 6 & 8 & 8 & 4 & 5 & 2 & 3 \\
\hline Gingiva & 25 & 9 & 3 & 8 & 5 & 10 & 0 & 0 \\
\hline Floor & 10 & 0 & 2 & 5 & 3 & 6 & 2 & 0 \\
\hline Cheek & 3 & 0 & 2 & 1 & 0 & 2 & 0 & 0 \\
\hline Total & 64 & 15 & 15 & 22 & 12 & 23 & 4 & 3 \\
\hline
\end{tabular}

* The grades are shown in Fig. 2.

$\dagger$ Deltopectoral skin flap

$\ddagger$ Pectoralis major myocutaneous flap

Table 5 Local Control and Survival Rate in the Subjects

\begin{tabular}{|c|c|c|c|c|c|c|c|c|}
\hline \multirow{2}{*}{ Site } & \multirow{2}{*}{ No. } & \multicolumn{2}{|c|}{ Local control failure } & \multirow{2}{*}{$\begin{array}{l}\text { Overall } \\
\text { control }\end{array}$} & \multicolumn{4}{|c|}{ Survival rate $(\%)$} \\
\hline & & primary & secondary & & $1 \mathrm{Y}$ & $2 \mathrm{Y}$ & $3 \mathrm{Y}$ & $5 \mathrm{Y}$ \\
\hline Tongue & 26 & 3 & 1 & $96.2 \%$ & 100 & 86.9 & 81.1 & 74.3 \\
\hline Gingiva & 25 & 5 & 2 & $92.0 \%$ & 92.0 & 81.8 & 71.2 & 61.0 \\
\hline Floor & 10 & 2 & 1 & $90.0 \%$ & 100 & 77.8 & 64.8 & 64.8 \\
\hline Cheek & 3 & 0 & 0 & $100 \%$ & 100 & 100 & 100 & 100 \\
\hline Total & 64 & 10 & 4 & $93.8 \%$ & 96.7 & 87.0 & 75.9 & 69.4 \\
\hline
\end{tabular}

れており, 全体では23例に DP 皮弁, 4 例に MC 皮弁, そして 3 例に舌分割皮弁が適用された。

局所再発は64例中10例にみられた。これらのうち 6 例は二次的に制御し得，最終的な局所制御率は $93.8 \%$ であった（Table 5)。局所制御率を部位別にみると， 舌がやや良好なものの部位による違いはほとんど認め られなかった。Kaplan-Meier 法による 5 年累積生存 率は舌癌： $74.3 \%$, 下顎歯肉癌： $61 \%$, 口底癌 : 64.8 $\%$, 煩粘膜癌 : $100 \%$ であり, 下顎歯肉癌, 口底癌でや や低値であったが,特に部位による差は明らかでなく, 全体では $69.4 \%$ であった。なお，死因としては腫瘍死 (16例), 他病死 (14例) がほぼ等しく, 歯肉癌症例に 他病死が多く含まれていた。
舌および口底癌患者における発語明瞭度は多くの例 で良好に保たれていた。すなわち，36例中21例には障 害は認められず, 残る15例に障害が後遣された(Table 6)。この15例のうちの 10 例は明瞭度 II, つまり軽度の 障害であり, 強度に障害された明瞭度 III, そして IV は, それぞれ 3 例， 2 例と少数例であった。T-stage との 関係では, T1症例に発語障害は認められず, T2症例は 16例中12例の発語は良好であった。しかしながら, 残 る 4 例のうち 3 例に明瞭度 II, そして 1 例に明瞭度 III の障害が認められた。T3症例では 12 例中 7 例の発語は 障害され，このうち 5 例の障害程度は軽度であったも のの, 残る 2 例はそれぞれ明瞭度III，およびIVであっ た。そしてT4になると発語障害はさらに高くなり，6 
Table 6 Relation between T-stage and Speech Intelligibility in 36 Tongue and Mouth-floor Cancer Patients

\begin{tabular}{ccccccc}
\hline \multirow{2}{*}{ T-stage } & No. of & \multicolumn{5}{c}{ Speech intelligibility } \\
\cline { 3 - 7 } & cases & I & II & III & IV & V \\
\hline T 1 & 2 & 2 & 0 & 0 & 0 & 0 \\
T 2 & 16 & 12 & 3 & 1 & 0 & 0 \\
T 3 & 12 & 5 & 5 & 1 & 1 & 0 \\
T 4 & 6 & 2 & 2 & 1 & 1 & 0 \\
\hline Total & 36 & 21 & 10 & 3 & 2 & 0 \\
\hline
\end{tabular}

Speech intelligibility

grade I : No impaired (Speech intelligibility of monosyllable is $100 \%$ )

$\begin{array}{ll}\text { II : Slightly impaired } & (\geqq 95 \%) \\ \text { III : Moderately impaired } & (\geqq 80 \%) \\ \text { IV : Severely impaired } & (\geqq 50 \%) \\ \text { V : Hardly to be listened } & (<50 \%)\end{array}$

Table 7 Influence of Induction Therapy on Threshold of Gustation

\begin{tabular}{lcccc}
\hline \multirow{2}{*}{ Gustation } & \multicolumn{4}{c}{ Time } \\
\cline { 2 - 5 } & Before & Preoperation $*$ & $3 \mathrm{M}$ after $\dagger$ & 1 Y after $\ddagger$ \\
\hline Sweet & $3.87 \pm 1.22$ & $4.93 \pm 1.28$ & $4.67 \pm 1.14$ & $4.46 \pm 1.39$ \\
Salt & $4.19 \pm 1.53$ & $5.44 \pm 0.80$ & $5.11 \pm 0.85$ & $4.77 \pm 0.65$ \\
Acid & $4.02 \pm 1.00$ & $5.05 \pm 0.95$ & $4.71 \pm 0.98$ & $4.28 \pm 1.08$ \\
Bitter & $3.90 \pm 1.33$ & $5.21 \pm 0.87$ & $4.55 \pm 0.98$ & $4.29 \pm 1.21$ \\
\hline
\end{tabular}

*: After the end of induction therapy

$\dagger, \ddagger$ : After the end of treatment

例中 4 例は明瞭度 II 〜 IVであった。全体的にみると T -stage の進行と共に, 発語障害の頻度も高くなる傾向 がうかがえた。

味覚閾值は 4 つの基本味覚とも導入療法と共に上昇 していた（Table 7）。調べた味覚の中では苦味が最も 治療の影響を受け，治療前には3.9土1.3であった閾値 が導入治療後には5. $2 \pm 0.9$ に上昇した。多少の程度の 差はあるものの,いずれの味覚も同じパターンを示し， 導入治療終了後に最も閾值は上昇し，治療終了 3 か月
後には各味覚ともある程度回復し, 治療後 1 年にはほ ぼ治療前のレベルにまで復していた。しかしながら， 塩味における閾值は治療前に比し充分な回復が得られ なかった。唾液分泌量（SFR）も治療に伴い低下し， 導入治療終了後には治療前の $62 \% ， 3$ か月後では 57.6 $\%$ ，そして 1 年後には約 $50 \%(0.24 \pm 0.2 \mathrm{ml} /$ 分）まで 減少していた（Table 8)。SFR の低下と呼応して唾液 粘稠度は持続的に上昇し, S-IgA 減少も導入治療終了 後を中心にして観察された。粘稠度は治療前に比し 1 
Table 8 Influence of Oral Cancer Therapy on Salivary Function

\begin{tabular}{ccccc}
\hline Items & \multicolumn{4}{c}{ Time } \\
\cline { 2 - 5 } examined & Before & Preoperation $\S$ & 3 M after & 1 Y after \\
\hline SFR $※(n=50)$ & 100 & 62.28 & 57.58 & 51.21 \\
Viscosity $\dagger(n=32)$ & $23.0 \pm 17.0$ & $33.4 \pm 18.8$ & $37.9 \pm 23.6$ & $38.4 \pm 30.4$ \\
S-IgA $\ddagger(n=31)$ & $88.0 \pm 53.4$ & $78.8 \pm 64.2$ & $109.0 \pm 88.7$ & $113.4 \pm 67.0$ \\
\hline
\end{tabular}

※: Salivary flow rate $=\frac{\text { salivary flow after treatment }}{\text { original salivary flow }} \times 100(\%)$

$\dagger$ : Each value represents mean $\pm \mathrm{SD}(\mathrm{mPa} \cdot \mathrm{S})$

$\ddagger$ : Each value represents mean $\pm \mathrm{SD}(\mu \mathrm{g} / \mathrm{ml})$

$\S:$ After the end of inductive chemo-radiotherapy

年後にはほぼ1.7倍となり, S- $\mathrm{IgA} は 88.0 \pm 53.4 \mu \mathrm{g} / \mathrm{ml}$ より導入治療終了後には $78.8 \pm 64.2 \mu \mathrm{g} / \mathrm{ml}$ に低下した が, 治療後 1 年ではある程度上昇していた。

\section{考 察}

口腔癌の治療にあたっては癌の根治もさることなが ら, 咀嚼, 嚥下, 構音・発声, 味覚, さらには運動機 能など，日常生活に欠くことのできない機能を障害せ ず，かつ審美障害を可及的に軽減することが重要な課 題となる ${ }^{16,17,18)}$ 。口腔癌の治療の主柱が手術療法, 化学 療法, 放射線療法であることは現在でも変わりなく, これらはいずれにおいても少なからず口腔諸機能を損 傷し，機能障害を来す。良好な局所制御と生存率を保 持しつつ, 口腔機能の損傷を避けうる治療が望まれる ところではあるが, そのような治療法は今のところ得 られていない。必然，各治療法を上手に組み合わせ， 各々のマイナス要因を減弱せしめることが，今日にお ける手段となるであろう。

近年, “induction chemotherapy"が頭頸部癌に導入 され良好な結果が示されてきた4 7)。われわれは早くよ りこの考え方をさらに発展させ, 導入治療として, 化 学療法と放射線療法との同時併用を積極的に行ってき た。そして，導入療法の臨床効果を判断した上で，外 科的治療の適応と切除範囲を決定し, 可及的に縮小切 除を試みてきた ${ }^{10,11,19,20)}$ 。この積極的な術前治療に続 く機能保存を考慮した，いわゆる保存的手術が，癌の 制御と共に口腔諸機能の保存にどの程度貢献している のかを知ることは, 今後の口腔癌治療の方針, そして 治療法を選択する上で必要であろう。そこで, 本論文
では口腔の諸機能が口腔癌治療によって, どの程度影 響を受けるかの検討を含め，われわれの行ってきた積 極的な導入治療とその後に続く保存的外科治療の有用 性を検討してみた。

本対象患者の治療時間に扔ける導入治療の一応の基 準は，PLM : 45〜50mg一 ${ }^{60} \mathrm{Co}: 26 〜 30 \mathrm{~Gy}$ ，あるいは CDDP : $120 \mathrm{mg} / \mathrm{m}^{2}-\mathrm{PLM}: 35 \sim 40 \mathrm{mg}-{ }^{60} \mathrm{Co}: 20 \sim 26 \mathrm{~Gy}$ とした。これらに加え，外照射の直前に日々，5-FU $(250 \mathrm{mg})$ を静脈内，ないしは支配動脈内へ注入した。 これらの適用は，患者の全身状態，原発巣の大きさ， 顎骨への浸潤あるいはリンパ節転移の有無等の臨床所 見，さらには組織学的所見 (浸潤様式 ${ }^{21)}, \mathrm{CD} 8$ 細胞の 浸潤程度 ${ }^{22)}$ や基底膜の状態23)，および免疫学的(Natural killer 活性）検査結果 ${ }^{21)}$ によって決定された。外照 射は原則として，腫瘍径が $3 \mathrm{~cm}$ 未満で骨への湿潤がな いもの以外に行った。われわれはこの化学・放射線治 療を "induction therapy" の中に位置づけてはいるも のの, 外科的処置にはこだわらず, CR が得られた場合 には，そのまま経過を観察することとしている。この ような積極的な導入療法により，CR が得られずとも $90 \%$ 以上の腫瘍縮小が得られたならば，われわれが以 前に報告した如く20)，縮小手術，つまり外科的安全域 （Surgical safe margin）を附与することなく切除する ことが可能である。そこで先ず臨床効果についてみて みると，90\%以上の腫崵縮小は39例（61\%）に得られ， CR22例，PR17例となっていた。また，pR'の22例にお いても 5 例は縮小率が $80 \%$ 前後とかなりの効果が得ら れていた。その結果, 全体の約 $2 / 3$ の症例に対し縮小手 術（ほとんど safe margin を附与しないか，あるいは 
safe margin をマイナスとする=治療前の腫瘍大より 小さく切除) が適応され得ることとなった。

われわれの意図とする縮小手術とは, 腫瘍縮小を計 った上で, safe margin を附与せず, 本来癌組織であっ た部位にメスを入れることを意味し，そのことより機 能を保存しょうとするものである。保存的な切除がど の程度に施行し得たかをより明確にするために，切除 量一範囲を各部位において 4 段階に分け (Fig. 2) 検討 してみた。その結果，I 度，つまりかつての腫瘍中心 部に対する生検切除か, $\mathrm{CR}$ で外科処置を受けないま まに経過観察された症例が64例中15例であった。そし て，表層部あるいは辺縁部の切除ですまされた grade IIが15例にのぼり，この両者を合わせた 30 例において は，切除による障害はほとんど認められていない。そ して, grade IIIの切除は対象の約 $1 / 3$ の症例に行われ, その多くは T3症例で, 一部に T4症例が含まれてい た。方法の項で述べた如く, grade IIIでは, 下顎骨の 連続性は保たれ，煩部の皮膚は保存され，口底・舌の 切除量も T3腫瘍に対する根治術と対比すると，はる かに少なく機能保存的である。保存的な切除が多数に おいて施行されたことは, 再建処置の内容をみると, さらに鮮明となる。切除後の組織欠損の補填に他部組 織が用いられたのは27例で，そのほとんどは DP 皮弁 であった。このような結果からすると積極的な導入療 法は十分に評価されうるように思われる。

導入療法を行うにあたって問題となるのは, 臨床効 果をどのように, いつ判断し，そしていかに治療の継 続, 終了, 手術を決定するかである。口内炎等の副作 用のために，治療の中断，中止をせざるを得ない場合 を除き, 予定量の照射と化学療法が行われた時点で, 臨床効果を判断すると共に，それから先の予測を行う こととしている。臨床経過より, それ以上, 保存的治 療を続けても十分な効果が得られず, 副作用のみが強 調されると考えられるケースには，縮小した腫瘍の大 きさ (臨床効果) に応じた手術を決定し, CR と考えら れた場合には，そのまま治療を終了するか(頸部郭清 の必要がある場合には 3 週間以内に郭清術を施行), 患 者の状態が許すならば，今少し化学・放射線の追加治 療を行うこととしている。

積極的な導入療法の効果は組織学的にも確かめられ た。58例の切除物において, その組織学的効果をみて みると, 53 例に grade II b 以上の腫瘍変性が得られて おり，この中には20例の grade IVないしIIIが含まれて
いた。これにCR で経過良好の 6 例を加えると, 生存癌 細胞の存在が否定され得るものが26例となり, 対象の 約 $40 \%$ に達していた。一方, grade II a 以下は 5 例認 められたが，これらの症例における特徵的な点は見出 せず，治療前に治療効果を予測することは無理のよう である。

臨床効果が良好な時に, 縮小手術が本当に許される ためには, 臨床効果と組織学的効果との間に相関性が なくてはならない。当科基準の臨床的効果と組織学的 効果とは良く相関し，CRでは grade IVを中心にいず れも II b 以上であり, PR では grade IIIおよびII bが ほとんどで, $\mathrm{pR}^{\prime} て ゙ は \mathrm{II} \mathrm{b}$ に少数例の II a が混在して いた。このように臨床効果と組織学的効果が相関して いたことは, 臨床効果を基に切除量を調節することの 妥当性を示すものと考えられる。

縮小手術を施行した場合, 癌組織が完全に切除し得 たかどうか危惧されるが, 局所再発は64例中10例と少 ない結果であった。この 10 例のうち 6 例は二次的に制 御され, 最終局所制御率は $93 \%$ と高值であった。著者 らは, 以前に組織標本上に扔いて, 切除断端と浸潤癌

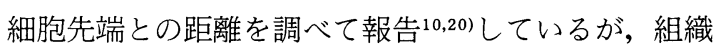
切片上での Safe margin は Surgical safe margin と は関連せず，臨床的・組織学的効果に関連していた。 つまり，術前治療によって十分な腫瘍縮小が得られた 症例に対し縮小手術を行ったとしても，その切除断端 と浸潤癌細胞先端との距離は十分であることが示され た。実際, 再発例をみると, そのほとんどが $5 \mathrm{~mm}$ 以下 の Safe margin を附与された $\mathrm{pR}^{\prime}$ 例であり, 組織学的 には grade II a の効果のものであった。 5 年累積生存 率をみると，全体では $69.4 \%$ と他家の報告24,25) より高 率であり，この大きな原因は良好な局所制御によるも のと思われる。

実際に化学・放射線併用療法を進めるに当たって, 最も問題となるのは, 粘膜炎である。著者らも, これ に対し種々対応策を試みてはいるが，実効はほとんど 得られていない26)。後述する導入治療による口腔の機 能障害と共に, 口内炎に対する今以上の配慮が必要で あろう。積極的な化学・放射線治療の今一つの問題点

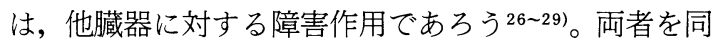
時に併用すればそれだけ副作用も強くなることは容易 に考えられる。対象患者の中に, 術後, 骨髄抑制と腎 障害，および導入治療後に生じた肺炎をそれぞれ 1 例 ずつ経験した。下に述べる口腔の機能障害も含め, 可 
及的に用量を減じなくてはならず，その目的に沿うべ く, 現在では他の療法,つまり Lymphokine activated killer（LAK）療法と Biological response modifyer （BRM）投与を併用 L， ${ }^{60} \mathrm{Co}: 20 \sim 25 \mathrm{~Gy}, \mathrm{PLM}$ ： 30〜 40mg程度を目指し導入療法を施行中である。

機能と社会生活は密接な関係があり，中でも言語機 能の障害は日常生活に支障を来すこととなる ${ }^{16,18)}$ 。言 語障害は舌・口底癌の36例中15例にみられたが，強い 障害（音声明瞭度 $80 \%$ 以下）は，わずかに 2 例のみで あった。これは術前治療を積極的に行い，縮小手術を 多くに適用した証であるが，われわれは舌尖部を主体 とした可動部が構音に最も強く影響するものと考え， 舌切除を行う際，可及的に舌尖部を保存するよう心掛 けている。実際，舌全体としては可動性がそしくとも， 舌尖部が保存されよく可動する場合には，構音はあま り傷害されていなかった。一方, “ボリューム”を附与 することも発音には大切で, 牛嶋らは年根部の重要 性を強調している。つまり, 舌の構音機能はボリュー ムを含めた形態と可動性, 特に舌尖部の運動性の両要 素からなるとみなすことができ，これら舌切除に際し 留意すべき点と考えられる。

味覚障害は, 導入治療が終了した後が最も著明とな り，各閾值は大きく上昇していた。そして，低下した 味覚は術後 3 か月には回復傾向が認められ, 術後 1 年 の時点では治療前のレベル近くまで回復した。Conger らは ${ }^{31)}$, 放射線性味覚障害の改善に要する時間は照射 終了後60～120日としており，われわれとほぼ一致した 結果を報告している。放射線のみならず，化学療法剤 の投与によっても味覚障害が惹起されることが予想 32 されるが, ${ }^{60} \mathrm{Co} に よ る 30 \mathrm{~Gy}$ ぐらいまでの照射量, ある いは PLM60mg程の投与量では，その味覚障害はほと んど可逆性ではあると考えられる。しかし両者が併用 されると障害は加重されることが予測され，両者併用 時には, 用量の減少を計らなくてはならないであろう。 なお，味覚には唾液の関与が考えられ，放射線あるい は抗癌剤による唾液分泌低下が味覚の低下の一因にな っていることも考えられるが，本論文では，味覚はデ スク法で測定していることより，喠液分泌とここでの 結果とは直接の関連はないように思われる。ただ，唾 液分泌の低下が舌乳頭の萎縮を来し，味蕾を障害した 可能性は否定できないであろう。

唾液腺の唾液分泌機能は, 味覚とは異なり進行性で 治療後 1 年間低下し続けた。放射線による唾液腺障
害 ${ }^{31,33,34)}$ は検討されているが, 抗癌剤の影響について はほとんど検索されていない17.18)。不可逆的な唾液腺 障害は弱いながらも化学療法のみで治療された患者に おいても観察され，PLMによる唾液分泌の低下は本 剂の有する線維化学作用からして, 腺房細胞への影響 よりも間質の線維化，血管の線維化による血液供給の 低下の方を考えるべきであろう。漿液性腺房細胞は放 射線に最も感受性を示し，照射により漿液細胞は変

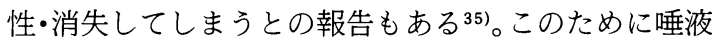
の生成は極度に低下することとなり，分泌量の低下と 共に粘稠度の上昇, さらには, S-IgA の減少を招き, カンジダ菌の上皮細胞への付着が増長されることとな る $^{36,37) 。}$

口腔癌患者に対する quality of life を治療との関連 から深く追求したものは見当たらない。口腔癌に対す る積極的な化学・放射線同時併用は強い粘膜炎を惹起 し，骨髄抑制，腎，肝機能障害を招来する可能性があ る。そして, 治療後には唾液腺機能・味覚障害を遺す ことになる。一方，手術による組織欠損は，再建外科 により，いかにそれが他の組織で補填されようとも機 能障害を来すこととなる。われわれの経験症例におい ては，術前治療を積極的に行うことによって，多くの 症例に㧈いて切除術を避け得ることとなり，切除をす るにしても保存的な切除が可能で，良好な局所制御と 機能保存が得られた。しかしながら，導入治療による 副作用を無視することは出来ず，今後，ますます増え るであろう高齢癌患者に対する治療27,38)をも見据えな がら, 導入療法を検討する必要があるように思われる。 導入治療による患者の負担を軽減するために，他の療

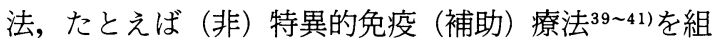
み入れ，より障害の少ない口腔癌の集学的治療を工夫 することが今後とも続けられなくてはならないであろ う。

\section{結＼cjkstart語}

口腔扁平上皮癌64例（一次症例）に対し，導入治療 として化学・放射線治療を行い, 腫瘍の縮小に応じて 保存的切除を行った。

1. 導入治療の臨床効果は, CR22例, PR17例, $\mathrm{pR}^{\prime} 22$ 例, NR 3 例であった。半連続切片における組織学的 な検索より,Grade IV : 16例, III : 4 例, II b : 33例,

II a：4例，I：1 例の各組織学的効果が認められ, 組織学的効果と臨床効果との間には相関が認められ 
た。

2. 切除量・範囲を 4 段階に分けた。30例は舌辺縁切 除, あるいは口底・煩の限局した切除あるいは歯肉一 歯肉辺縁切除 (grade I およびII) までですまされて いた。これに対し, grade $\mathrm{I}$ の煩部切除 (広範全層切 除)は 1 例もなく，周囲組織を含め舌の $1 / 3$ を越える 切除, あるいは pull-through 手術が施行されたのは 舌・口底癌合わせた 36 例のうちの 7 例にすぎなかっ た。さらに，25例の下顎歯肉癌の中で，わずか 5 例 に下顎片側切除ないしは区域切除が施行された。保 存的切除が可能であったことより, 再建術は少数例 にしか施行されず，DP 皮弁による即時再建が23例 に，MC 皮弁はわずかに 4 例に用いられた。

3. 発語検査を36例の舌・底癌症例で行ったところ, 15例に発語障害が認められたが，中程度ないしは強 度の障害は 5 例にみられたにすぎなかった。

4. 味覚障害は治療と共に増悪したが, 治療後 1 年の うちに元のレベル近くまで回復した。無刺激唾液分 泌量は徐々に低下し, 治療後 1 年には治療前の約半 分にまで低下した。これに伴い粘稠度の上昇および S-IgA が低下した。

5. 64例のうち10例に局所再発が認められたが， 6 例 は二次的に制御し得, 最終局所制御率は $93.8 \%$ で, 5 年生存率は $69.4 \%$ であった。

以上より, 化学・放射線の同時併用による積極的な 導入治療は保存的切除を可能にし, 審美性あるいは機 能上の障害を減じることが示された。しかし，一方で は, 味覚, 唾液分泌等を障害することより, 用量の減 少が望まれた。

本論文の要旨は, 第 9 回口腔腫場学会総会（1991年 4 月 1 日，大分）において発表した。

\section{文献}

1) Schipper. H., Clinch, J,. et al. : Measuring the quality of life of cancer patients : The functional living index-cancer : development and validation. J Clin Oncol 2 : 472-483, 1984.

2) American Society for Head and Neck Surgery : Papers from the second international conference on head and neck cancer. Arch Otolaryngol Head Neck Surg 115 : 295-315, 1989.

3) Donovan, K., Sanson-Fisher, R. W., et al. :
Measuring quality of life in cancer patients. J Clin Oncol 7 : 959-968, 1989.

4) Hong, W. K., Bhutani, R., et al. : Induction chemotherapy of advanced previously untreated squamous cell head and neck cancer with Cisplatin and Bleomycin. In. Status and New Developments. New York, Academic Press, Inc., 1980, 431-444.

5) Schuller, D. E., Wilson, H. E., et al. : Preoperative reductive chemotherapy of the oral cavity, oropharynx, and hypopharynx. Cancer 51 : 15-19, 1983.

6) Elias, G. G., Chretien, P. B., et al. : Chemotherapy prior to local therapy in advanced squamous cell carcinoma of the head and neck. Cancer 43 : 1025-1031, 1979.

7) Ervin, T. J., Clark, J. R., et al. : An analysis of induction and adjuvant chemotherapy in the multidisciplinary treatment of squamous cell carcinoma of the head and neck. J Clin Oncol 5 : 10-20, 1987.

8) Adelsetin, D. J., Sharan, U. M., et al. : Simultaneous versus sequential combined technique therapy for squamous cell head and neck cancer. Cancer 65 : 1685-1691, 1990.

9) Fu, K. K., Phillips, T. L., et al. : Combined radiotherapy and chemotherapy with bleomycin and methotrexate for advanced inoperable head and neck cancer : Update of Northern California Oncology Group randomized trial. J Clin Oncol 5 : 1410-1418, 1987.

10）尾崎登喜雄, 広田重水, 他：頭頸部癌 75 症例の臨 床的ならびに免疫・組織学的検討. 日口外誌 34 : 274-286. 1988.

11）広田重水, 米田和典, 他：口腔癌の集学的治療に おけるCDDPの臨床組織学的効果について一 $\mathrm{CDDP}$ 非使用群との比較検討. 日癌治 $26: 1110$ $-1118,1991$.

12) Hufnagle, J., Pwllon, P., et al. : Speech considerations in oral surgery. Part II Speech characteristics of patients following surgery for oral malignancies. Oral Surg 46 : 354-361, 1978.

13) Ben-Aryen, H., Gutman, D., et al. : Effects of 
irradiation on saliva in cancer patients. Int $\mathrm{J}$ Oral Surg 4 : 205-210, 1975.

14）広戸幾一郎：頭頸部がん治療効果判定基準（案), 日本頭頸部腫瘍学会治療効果判定基準委員会, 1985.

15) Shimosato, Y., Oboshi, S., et al. : Histological evaluation of effects of radiotherapy and chemotherapy for carcinomas. Jpn J Oncol 1 : 19-35, 1971.

16）冨田幸伸, 尾崎登喜雄：Induction therapy後, 手 術を施行した舌・口腔癌患者の発音機能について。 癌の臨床 $36: 163-168,1990$.

17) Tomita, Y., Osaki, T. : Gustatory impairment and salivary gland pathophysiology in relation to oral cancer treatment. Int J Oral Maxillofacial Surg 19 : 299-304, 1990.

18）冨田幸伸：導入一手術療法による口腔癌治療に伴 う舌および唾液腺障害について。 日口外誌 37 ： 1299-1312, 1991.

19) Leslie, M. H. : Hemitongue advancement following anterior hemiglossectomy. Plast Reconst Surg $71: 552-555,1982$.

20）大野彰彦, 尾崎登喜雄, 他：口腔扁平上皮癌にお ける術前治療効果からみた"safe margin"の検討. 日癌治 $21: 66-74,1986$.

21）尾崎登喜雄, 米田和典, 他：口腔粘膜癌のリンパ 節転移に関する免疫学的検討. 日癌治 $25: 63-73$, 1990.

22) Hirota, J., Ueta, E., et al. : Immunohistologic study of mononuclear cell infiltrates in oral squamous cell carcinomas. Head \& Neck 12 : 118-125, 1990.

23) Hirota, J., Yoneda, K., et al. : Basement membrane type $\mathrm{IV}$ collagen in oral squamous cell carcinoma. Head \& Neck 12 : 400-405, 1990.

24）金沢春幸, 谷本良司, 他：口腔癌の臨床統計一教 室過去 10 年の治療成績一, 日口外誌 $36: 87-95$, 1991.

25）美馬考至, 浦出雅裕, 他：当科における過去 9 年 間（1978～1986）の悪性腫瘍の臨床統計的観察一 特に口腔打よび上顎洞扁平上皮癌症例につい て一. 日口外誌 34:349-356, 1988.

26）山本哲也, 米田和典, 他：頭頸部癌治療における
CDDPの副作用とシメチジン (CMT) の腎保護作 用について。 日ロ外誌 $37:$ 127-137, 1991.

27）加藤 斎, 尾崎登喜雄, 他：90歳以上の高齢口腔 癌患者の治療経験とその問題点. 癌の臨床 $32 ：$ 287-292, 1986.

28) Sleijfer, D. T., Offerman, J. J. G., et al. : The potective potential of the combination of uerapamil and cimetidine on cisplatin-induced nephrotoxicity in man. Cancer 60 : 2823-2828, 1987.

29) Weichselbaum, R. R., Clark, J. R., et al. : Combined modality treatment of head and neck cancer with cisplatin, bleomycin, methotrexate -leucovorin chemotherapy. Cancer 55 : 21492155, 1985.

30）牛嶋垟次郎, 広瀬 肇: 舌切除術後の構音機能に 関与する要因一自験例からの考察一. 音声言語医 学 $26: 209-214,1985$.

31) Conger, A. D., Wells, M. A., : Radiation and aging effect on taste structure and function. Radiat Res 37 : 31-49, 1969.

32) Dewys, W. D., Walters, K. : Abnormalities of taste sensation in cancer patients. Cancer 36 : 1888-1896, 1975.

33) Mossman, K. L. : Quantitative radiation doseresponse relationships for normal tissues in man. II. Response of salivary glands during radiotherapy. Radiat Res 95 : 392-398, 1983.

34) Mira, J. G., Wescott, W. B. : Some factors influencing salivary function when treating with radiotherapy. Int J Radiat Oncol Biol Phys $7:$ 535-541, 1981.

35) Tatemoto, Y., Hirota, J., et al. : Histochemical studies on irradiated and obstructive human submandibular glands. Protein destribution and lectin-binding in the degenerative glands. Bas Appl Histochem 34 : 59-70, 1990.

36) Williams, R. C., Gibbons, R. J. : Inhibition of bacterial adherence by secretory immunoglobulin A : a mechanism of antigen disposal. Science $177:$ 697-699, 1972.

37) Vudhichamnong, K., Walker, D. M., et al. : The effect of secretory immunoglobulin $\mathrm{A}$ on the in 
vitro adherence of the yeast candida albicans human oral epithelial cells. Arch Oral Biol 27 : 617-621, 1982.

38）米田和典, 尾崎登喜雄, 他：高齢者の口腔癌治療 における副作用と合併症について。 日口外誌 40 : 432-444, 1991.

39）米田和典, 山本哲也, 他：OK-432 と共に化学療 法, 放射線治療を行った頭頸部癌患者における免 疫学的検討. 臨床免疫 $19: 618-626,1987$.
40) Yoneda, K., Ueta, E., et al. : Immunoregulatory effects of Sizofiran (SPG) on lymphocytes and polymorphonuclear leukocytes. Clin Exp Immuno1 $86: 229-235,1991$.

41) Tanida, S., Uchida, H., et al.: Marked reduction of subcutaneous tumor growth by intraperitoneal administration of recombinant human interleukin-2 with a cell accumulator, protease -peptone, in mice. Cancer Res $49: 284-288,1989$.

\title{
Induction chemo-radiotherapy and conservative surgery to oral carcinomas with the aim of minimum oral dysfunction
}

\author{
Tokio Osaki, Jyusui Hirota, Kazunori Yoneda, \\ Tetsuya Yamamoto, Eisaku Ueta \\ Department of Oral Surgery, \\ Kochi Medical School \\ (Cheif : Prof. Tokio Osaki)
}

\begin{abstract}
Induction chemoradiotherapy was preoperatively applied to 64 primary oral squamous cell carcinomas aiming at reductive excision with preservation of the oral functions. The subjected tumors were composed of $2 \mathrm{~T} 1,27 \mathrm{~T} 2,22 \mathrm{~T} 3$ and $13 \mathrm{~T} 4$. The tumors were treated with both ${ }^{60} \mathrm{Co}$ and PLM in 5, PLM +5-FU in 44, 5-FU+CDDP in 1 and PLM+5-FU+CDDP in 14 cases. Clinically, CR was observed in $22, \mathrm{PR}\left(\geqq 90 \%\right.$ remission) in $17, \mathrm{pR}^{\prime}$ ( $\geqq 50 \%$ ) in 22 and NR ( $<50 \%)$ in 3 cases. Histopathologically, cells of 16 tumors exhibited a Grade NV degenerative change, and Grade III, IIb, IIa and grade I degeneration were observed in 4, 33, 4 and 1, respectively, having a correlation to the tumor remission rates. Conservative surgery was performed evaluating the tumor response, and surgical extent was divided into 4 grades. Excision of grade I (only observation without surgery or excisional biopsy) and grade II (marginal tongue resection, limited mouth floor or cheek excision and alveolectomy) was applied to 15 cases each, further, operation of grade III (within $1 / 3$ tongue ectomy with limited removal of the surrounding tissues, limited pull through excision, skin - conservated wide cheek excision and above canal mandibulectomy) and grade IV (each extended radical excision) was indicated to 22 and 12 cases, respectively. The extirpated defects were immediately supplemented with deltopectoral skin flap and major pectoral musculocutaneous flap in 23 and 4 cases, respectively. Speech was impaired in 15 among 36 tongue and mouth floor tumor cases. Gustatory impairment increased after induction therapies exhibiting recoveries to near the original levels within a year. Resting salivary flow rate subsequently decreased and finally lowered to about $50 \%$ of the original accompaning increase of the viscosity and contrary decrease of secretory IgA level. No local recurrence was resulted except for 10 cases where 6 were secondarily controlled, and 5 year survival rate was estimated as $69.4 \%$. In conclusion, aggressive induction therapy with synchronous chemo and radiotherapy makes
\end{abstract}


conservative surgery possible, and will minimize cosmetic and functional disabilities. However salivary gland damage and gastatory impairment remain unsolved.

Key words : Oral carcinoma, Induction therapy, Clinicohistopathologic effects, Conservative surgery, Oral functions 